\title{
Coupling organosolv fractionation and reductive depolymerization of woody biomass in a two-step catalytic process
}

\section{Citation for published version (APA):}

Ouyang, X., Huang, X., Hendriks, B. M. S., Boot, M. D., \& Hensen, E. J. M. (2018). Coupling organosolv fractionation and reductive depolymerization of woody biomass in a two-step catalytic process. Green Chemistry, 20(10), 2308-2319. https://doi.org/10.1039/c8gc00639c

DOI:

10.1039/c8gc00639c

Document status and date:

Published: 21/05/2018

\section{Document Version:}

Typeset version in publisher's lay-out, without final page, issue and volume numbers

\section{Please check the document version of this publication:}

- A submitted manuscript is the version of the article upon submission and before peer-review. There can be important differences between the submitted version and the official published version of record. People interested in the research are advised to contact the author for the final version of the publication, or visit the DOI to the publisher's website.

- The final author version and the galley proof are versions of the publication after peer review.

- The final published version features the final layout of the paper including the volume, issue and page numbers.

Link to publication

\footnotetext{
General rights

- You may freely distribute the URL identifying the publication in the public portal. follow below link for the End User Agreement:

www.tue.nl/taverne

\section{Take down policy}

If you believe that this document breaches copyright please contact us at:

openaccess@tue.nl

providing details and we will investigate your claim.
}

Copyright and moral rights for the publications made accessible in the public portal are retained by the authors and/or other copyright owners and it is a condition of accessing publications that users recognise and abide by the legal requirements associated with these rights.

- Users may download and print one copy of any publication from the public portal for the purpose of private study or research.

- You may not further distribute the material or use it for any profit-making activity or commercial gain

If the publication is distributed under the terms of Article $25 \mathrm{fa}$ of the Dutch Copyright Act, indicated by the "Taverne" license above, please 


\section{Journal Name}

\section{ARTICLE}

\section{Coupling organosolv fractionation and reductive depolymerization of woody biomass in a two-step catalytic \\ process}

Received 00th January 20xx, Accepted 00th January 20xx

DOI: $10.1039 / x 0 x \times 00000 x$

www.rsc.org/

\author{
Xianhong Ouyang ${ }^{a}$, Xiaoming Huang *a, Bart M. S. Hendriks ${ }^{a}$, Michael D. Boot ${ }^{b}$ and \\ Emiel J. M. Hensen *a
}

\section{Introduction}

Lignocellulose is an abundant biorenewable resource with the potential of becoming a sustainable feedstock for the manufacture of chemicals and fuels. ${ }^{1}$ For this purpose, it is necessary to use physical, chemical or biological processes to break down the strongly interlinked lignocellulose structure in the plant cell walls that is made up from cellulose, hemicellulose and lignin in order to selectively convert the various components. 2 In an optimized bio-refinery, the various fractions can then be converted to valuable products. For example, the cellulose and hemicellulose fractions can be converted into glucose and other sugars, which are intermediates for the production of platform chemicals such as 5-hydroxymethylfurfural, furfural, furfuryl alcohol, and levulinic

a. Schuit Institute of Catalysis, Inorganic Materials Chemistry, Eindhoven University of Technology, P.O. Box 513, 5600 MB Eindhoven, The Netherlands.

E-mail: e.j.m.hensen@tue.nl x.huang@tue.nl

b. Combustion Technology, Department of Mechanical Engineering, Eindhoven University of Technology, P.O. Box 513, 5600 MB Eindhoven, The Netherlands. acid. ${ }^{3}$ Another approach is to ferment glucose and other sugars into ethanol, which can serve as a fuel or as a base chemical. Lignin can in principle be used to produce phenols, aromatics and other chemical intermediates. ${ }^{4}$ The upgrading of lignin is less established than upgrading of (hemi)cellulose, mainly because of its structural complexity, heterogeneity and low reactivity. ${ }^{5}$

There already exist a wide variety of processes to isolate lignin from lignocellulose for different purposes. In the pulp and paper industry, lignin is a by-product from cellulose fibre production by sulphite, Kraft or soda pulping. ${ }^{6}$ This lignin by-product is mostly burnt to recover the energy content. Current biorefinery setups aim to maximize the yield of polysaccharides and usually treat lignin as a low-value by-product. ${ }^{7}$ Nevertheless, in recent years it has been realized that valorization of the lignin fraction is important to increase the overall economics of a biorefinery. ${ }^{8}$ A wide range of pre-treatment methods have been developed such as steam explosion and organosolv processing. ${ }^{9,10,11}$ Organosolv pulping is one of the more promising methods and has already been demonstrated at the pilot scale. Typical organosolv processes are performed in a mixture of water and an organic solvent, usually alcohols, at a temperature below 200 
${ }^{\circ} \mathrm{C}$. Acids such as sulfuric acid, hydrochloric acid formic acid and acetic acid can be used as catalysts to improve the process efficiency. Lignin from organosolv pulping is mainly recovered as a solid product by addition of acidified water. This type of lignin has a high purity and low ash content and has accordingly been the object of catalytic conversion studies that target fuels and chemicals. ${ }^{12,13}$ Typical monomer yields are low because during lignin extraction and downstream recovery steps, undesired condensation reactions take place. These reactions lead to recalcitrant $\mathrm{C}-\mathrm{C}$ bonds, rendering the resulting lignin unreactive towards mild depolymerization.

Recently, a strategy towards lignocellulose upgrading has been advocated that aims to convert the native lignin in the biomass directly upon release from the lignocellulosic matrix into monomers. Various terms have been used for this approach such as "lignin-first process" (LFP), "reductive catalytic fractionation" (RCF) and "early-stage catalytic conversion of lignin" (ECCL). ${ }^{14,15}$ Lignin extraction and catalytic depolymerization of lignin fractions can be done in one pot. For instance, $\mathrm{Xu}$ et al. demonstrated that the lignin in birch wood can be converted to phenolic monomers using a $\mathrm{Ni}$-based catalyst in a combined fragmentation-hydrogenolysis process. ${ }^{16}$ Sels et al. reported the reductive conversion of birch sawdust into phenolic monomers over a Ru/C catalyst in methanol through simultaneous solvolysis and hydrogenolysis. ${ }^{17}$ Moreover, the effect of solvents, acid/base additives and different redox catalysts are further investigated to improve the lignin monomer yield and carbohydrate retention in LFP. ${ }^{18,} 19$, 20 We have demonstrated that metal triflates can effectively catalyze the release of lignin fragments from the biomass matrix during reductive fractionation..$^{21}$ In this approach, the dissolved lignin fragments are rapidly depolymerised to phenolic monomers by $\mathrm{Pd} / \mathrm{C}$-catalyzed hydrogenolysis. ${ }^{22}$ Mineral acids can replace these metal triflates, decreasing the process costs. ${ }^{23}$ Despite the promise of these reductive fraction processes, there are also some drawbacks. The recovery of heterogeneous catalysts remains a challenge, because it is mixed with the cellulose pulp residue. Several strategies have been proposed to separate the catalyst from cellulose residue. One approach is to use magnetic separation, which can be achieved for instance with $\mathrm{Ni}$ catalysts. ${ }^{16,24} \mathrm{An}$ alternative is to avoid the direct contact between the heterogeneous catalysts and the solid feedstock. For instance, reductive lignocellulose fractionation and lignin hydrogenolysis can be separated in two beds in a continuous flow process. Lignin is extracted in the first bed and converted to monomers by the catalyst (e.g., $\mathrm{Pd} / \mathrm{C}$ or $\mathrm{Ni} / \mathrm{C}$ mixed with $\mathrm{SiO}_{2}$ ) in the second bed. ${ }^{25,26} \mathrm{~A}$ third approach is to separate the two reaction steps, delignification and lignin depolymerization in two batch processes. Luterbacher et al. reported a two-step method involving the $\mathrm{HCl}$-catalyzed extraction of lignin in the presence of formaldehyde, thereby suppressing repolymerization. The extracted lignin oil was then converted to monomers by a $\mathrm{Ru} / \mathrm{C}$ catalyst. ${ }^{27}$

The two-step process shows good potential for lignocellulose fractionation and lignin valorization. The key point is to prevent

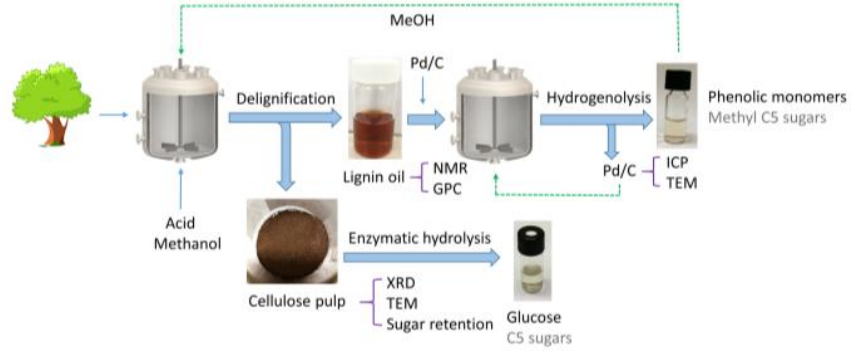

Scheme 1. Fractionation and catalytic conversion of woody sawdust.

lignin repolymerization during the fractionation step. In order to validate the feasibility of this strategy without using sacrificial reagents such as formaldehyde or diols, we investigated a twostep catalytic process (Scheme 1) in which lignocellulose is first delignified by a mineral acid followed by hydrogenolysis of the lignin oil to aromatic monomers by a Pd/C catalyst in methanol. This is different from the conventional depolymerization strategy using isolated organosolv lignin as feedstock, because the lignin oil is directly subjected to the hydrogenolysis step without downstream recovery of lignin in solid form. This potentially limits the condensation of lignin fragments. The main focus of this work is to optimize the first delignification step to minimize lignin repolymerization by using different types of acid, including $\mathrm{H}_{2} \mathrm{SO}_{4}, \mathrm{Al}(\mathrm{OTf})_{3}, \quad p$ methylbenzenesulfonic acid and $\mathrm{HCl}$. The released lignin fragments are analysed by gas chromatography/gas chromatography-mass spectrometry (GC/GC-MS), gel permeation chromatography (GPC) and heteronuclear single quantum coherence NMR (HSQC NMR) spectroscopy. Model compounds are employed to explore the role of the acids in the delignification process. Plausible mechanisms for delignification and lignin depolymerization and repolymerization are discussed. Pd/C can be easily separated and is further characterised to determine catalyst stability under the acidic conditions by elemental analysis and transmission electron microscopy (TEM). The possibility to valorize the cellulose pulp is explored by enzymatic hydrolysis to glucose.

\section{Results and discussion}

\section{Catalytic delignification and depolymerization of oak sawdust}

For a typical two-step experiment, oak sawdust was first fractionated in methanol using different acids at $160{ }^{\circ} \mathrm{C}$ at atmospheric pressure using $\mathrm{N}_{2}$. After reaction, the reaction mixture was subjected to filtration to separate the lignin oil from the cellulose pulp. The lignin oil was directly subjected to a second depolymerization step over $\mathrm{Pd} / \mathrm{C}$ catalyst at $180^{\circ} \mathrm{C}$ under 30 bar of $\mathrm{H}_{2}$. The delignification degree was determined based on the Klason lignin content in the cellulose residue and oak sawdust. The amount of acid catalyst has been earlier optimized based on a one-step catalytic approach. ${ }^{23}$ Table 1 summarizes the phenolic monomer yield, product distribution and delignification degree of the reactions involving different acids. 
Table 1 Results of delignification and lignin depolymerization of oak sawdust under different acid catalysts

\begin{tabular}{|c|c|c|c|c|c|c|c|c|c|c|}
\hline \multirow[t]{3}{*}{ Entry } & \multicolumn{5}{|c|}{ Delignification $^{a}$} & \multicolumn{5}{|c|}{ Depolymerization ${ }^{b}$} \\
\hline & \multirow{2}{*}{$\begin{array}{c}\text { Acid } \\
\text { catalyst } \mathrm{c}\end{array}$} & \multirow{2}{*}{$\begin{array}{c}\text { Delignification }{ }^{d} \\
(\%)\end{array}$} & \multicolumn{2}{|c|}{ Sugar retention (\%) } & \multirow{2}{*}{$\begin{array}{c}\text { Methyl } \\
\text { xyloside } \\
\text { (mg) }\end{array}$} & & & & \multirow[b]{2}{*}{$\mathbf{R}$} & \multirow{2}{*}{$\begin{array}{c}\text { Total } \\
\text { monomer } \\
\text { yield (wt } \\
\% \text { ) }\end{array}$} \\
\hline & & & $\mathrm{C}_{5} \mathrm{e}$ & $\mathrm{C}_{6}{ }^{\mathrm{f}}$ & & & & & & \\
\hline 1 & No acid & 30 & 83 & 98 & 51 & 11.9 & 0 & 1.2 & - & 13.1 \\
\hline 2 & $\mathrm{H}_{2} \mathrm{SO}_{4}$ & 70 & 27 & 95 & 211 & 0.8 & 1.6 & 0.9 & 14.5 & 17.8 \\
\hline 3 & $\mathrm{Al}(\mathrm{OTf})_{3}$ & 61 & 28 & 79 & 245 & 4.6 & 4.4 & 2.3 & 7.2 & 18.5 \\
\hline 4 & $p$-TsOH & 64 & 46 & 76 & 198 & 13.4 & 7.6 & 2.2 & 2.9 & 26.2 \\
\hline 5 & $\mathrm{HCl}$ & 47 & 63 & 74 & 153 & 18.5 & 6.1 & 2.0 & 0.8 & 27.4 \\
\hline 6 & $\mathrm{H}_{3} \mathrm{PO}_{4}$ & 44 & 83 & 89 & 54 & 19.5 & 0.9 & 2.2 & 2.4 & 25.0 \\
\hline $7^{\mathrm{h}}$ & $\mathrm{H}_{2} \mathrm{SO}_{4}$ & - & - & - & & 5.7 & 23.1 & 5.4 & 1.0 & 35.3 \\
\hline $8^{i}$ & $\mathrm{Al}(\mathrm{OTf})_{3}$ & - & - & - & & 7.4 & 20.7 & 5.5 & 0.7 & 34.3 \\
\hline
\end{tabular}

a Delignification condition: $2.0 \mathrm{~g}$ oak sawdust (particle size 125-300 $\mu \mathrm{m}, 23 \mathrm{wt} \%$ Klason lignin), methanol $40 \mathrm{ml}, \mathrm{N}_{2}$ atmospheric pressure at $\mathrm{RT}, 160^{\circ} \mathrm{C}$ (about 17 bars at $160^{\circ} \mathrm{C}$ ), $2 \mathrm{~h} .{ }^{\mathrm{b}}$ Hydrogenolysis condition: Lignin oil in methanol from delignification, $100 \mathrm{mg} 5 \mathrm{wt} \% \mathrm{Pd} / \mathrm{C}, 30 \mathrm{bars}$ $\mathrm{H}_{2}$ at RT $180^{\circ}$ (about 47 bars at $180^{\circ} \mathrm{C}$ ), $2 \mathrm{~h}$. ' ${ }^{\mathrm{c}}$ Acid dosage: The acid dosage is equivalent to the amount of Al (OTf) 3 (0.0316 mmol, $\left.15 \mathrm{mg}\right) .4$ $x$ equivalence of $\mathrm{H}_{2} \mathrm{SO}_{4}, p$-TsOH. $32 x$ equivalence of $\mathrm{HCl}$ and $\mathrm{H}_{3} \mathrm{PO}_{4}$. ${ }^{d}$ Based on the weight of Klason lignin in cellulose residue and the Klason lignin weight in oak sawdust. ${ }^{e} C_{5}$ sugars correspond to xylose and arabinose. ${ }^{f} \mathrm{C}_{6}$ sugars correspond to glucose. ${ }^{g}$ Lignin monomer yield after the hydrogenolysis by $\mathrm{Pd} / \mathrm{C}$. ${ }^{\mathrm{h}} 2.0 \mathrm{~g}$ oak sawdust, methanol $40 \mathrm{ml}$, $4 \mathrm{x}$ equivalence $\mathrm{H}_{2} \mathrm{SO}_{4}, 100 \mathrm{mg} 5 \mathrm{wt} \% \mathrm{Pd} / \mathrm{C}, 160{ }^{\circ} \mathrm{C}$. ${ }^{\mathrm{i}} 2.0 \mathrm{~g}$ oak sawdust, methanol $40 \mathrm{ml}, 1 \mathrm{x}$ equivalence of $\mathrm{Al}(\mathrm{OTf})_{3} 100 \mathrm{mg} 5 \mathrm{wt} \% \mathrm{Pd} / \mathrm{C}, 160{ }^{\circ} \mathrm{C}$.

Without acid, the delignification degree is only $30 \%$. In the presence of sulfuric acid, $70 \%$ of lignin can be extracted from oak sawdust. The $\mathrm{Al}(\mathrm{OTf})_{3}$ can also efficiently catalyze the release of lignin, which leads to a significant delignification degree of $61 \%$ at low acid concentration (entry 3). The use of $p$-TsOH (entry 4), a strong organic acid, also produces a nearly similar delignification degree (64\%) under optimized conditions. The result for $\mathrm{HCl}(47 \%)$ is lower than the results obtained in our previous study. ${ }^{23}$ This can be explained by the volatility of $\mathrm{HCl}$, as the delignification step was carried out at the atmospheric pressure in the present study. Similarly, $\mathrm{H}_{3} \mathrm{PO}_{4}$ is also less effective in extracting lignin from oak sawdust, as evidenced by the low delignification degree (44\%). These results show that $\mathrm{H}_{2} \mathrm{SO}_{4}, \mathrm{Al}(\mathrm{OTf})_{3}$ and $p$-TsOH acids are more effective in releasing lignin from oak sawdust compared with $\mathrm{HCl}$ and $\mathrm{H}_{3} \mathrm{PO}_{4}$ acids under relatively mild conditions.

The use of an acid hydrolysis step also releases some of the polysaccharides. In general, the retention of $\mathrm{C}_{6}$ sugars is much higher than that of $C_{5}$ sugars during acid delignification because of the high crystallinity of cellulose. Relatively speaking, the use of $\mathrm{Al}(\mathrm{OTf})_{3}, p-\mathrm{TsOH}$ and $\mathrm{HCl}$ results in more substantial cellulose conversion in the first step. The retention of $\mathrm{C}_{5}$ sugars strongly depends on the acid used. For example, the use of $\mathrm{H}_{3} \mathrm{PO}_{4}$ allows retaining $83 \%$ of the $C_{5}$ sugars and $89 \%$ of the $C_{6}$ sugars in the pulp. On the contrary, when the delignification step is carried out in $\mathrm{H}_{2} \mathrm{SO}_{4}$, most of the hemicellulose is dissolved and converted to methyl xyloside, while nearly all the cellulose (95\%) is retained as a solid pulp. Methyl xyloside can be separated from the lignin fragments, for instance by liquidliquid extraction using ethyl acetate/water. Methyl xyloside can then also be upgraded to valuable chemicals such as methyl levulinate. ${ }^{28}$ The released carbohydrate can also be dehydrated to furfural-type products, such as furfuraldehyde, 5hydroxymethylfurfural, 5-(methoxylmethyl)furfural in acid conditions. ${ }^{29}$ These products were not observed presumably due to the occurrence of lignin-furfural condensation reaction. ${ }^{30}$ Comparison of delignification degree and sugar retention data shows that a high degree of delignification is always accompanied by a large extent of $C_{5}$ sugar release.

After acid delignification, the lignin oil is further subjected to a hydrogenolysis step using $\mathrm{Pd} / \mathrm{C}$ in the presence of $\mathrm{H}_{2}$. The acid is not neutralized before the second hydrogenolysis step since the presence of acid can promote the depolymerization of lignin oil. ${ }^{23,31}$ For all the experiments, the hydrogenation of released carbohydrate was not observed and mainly four types of lignin monomers were produced, namely $\mathrm{P}_{-}-\mathrm{OCH}_{3}$ (4-n-methoxy propyl syringol/guaiacol), $\quad \mathrm{P}-\mathrm{OH} \quad$ (4-n-propanol syringol/guaiacol), $\mathrm{P}-\mathrm{H}$ (4-n-propyl syringol/guaiacol) and other structurally ill-defined lignin monomers (molecular weight < $226 \mathrm{~g} / \mathrm{mol}$ ). An important finding is that there is a negative correlation between delignification degree in the first step and the yield of lignin monomers in the second hydrogenolysis step. A higher delignification degree in the first step typically results in a lower monomer yield. For instance, the highest delignification degree was obtained for $\mathrm{H}_{2} \mathrm{SO}_{4}$, but only 17.8 wt\% of phenolic monomers was obtained after hydrogenolysis (entry 2). This also holds for experiments with the Al(OTf) catalyst (entry 3 ). One plausible explanation is that the lignin fragments have polymerised to form products with a higher molecular weight due to the formation of more stable $\mathrm{C}-\mathrm{C}$ bonds. The use of $p$-TsOH results in a good delignification degree (64\%) and a reasonable phenolic monomer yield $(26.2$ wt\%, entry 4). Conversely, the use of $\mathrm{HCl}$ in the first step yields $47 \%$ of lignin oil, which can be more easily depolymerized to monomers with a yield of 27.4 wt\%. Similar results can be obtained with $\mathrm{H}_{3} \mathrm{PO}_{4}$ (entry 6). Although the efficiency of the first step is lower, the resulting fragments can be depolymerized more easily.

The results for entries 1-6 illustrate that the use of acids can catalyze delignification of oak sawdust. Polymerization leads to higher molecular-weight fragments, which are more recalcitrant towards bond cleavage reactions. In current biorefinery operations, a high delignification degree is achieved 

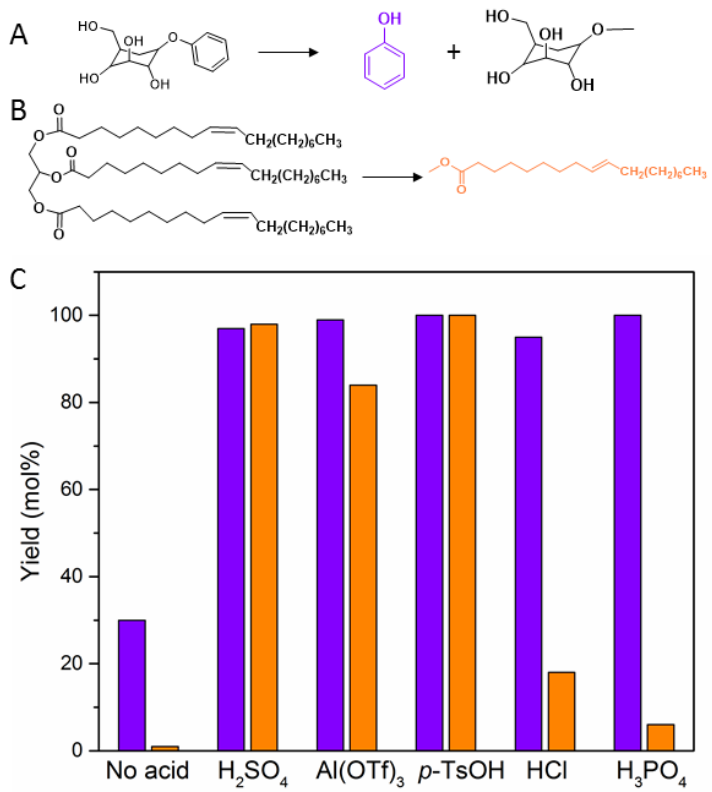

Figure 1 Catalytic results of the reactions of $(A)$ phenyl glycoside and $(\mathrm{B})$ glyceryl trioleate in methanol with varying acid catalysts at $160^{\circ} \mathrm{C}$ for $2 \mathrm{~h}$.

as high-quality cellulose is targeted. Then, the lignin fraction has a very low reactivity due to a high content of carbon-carbon lignin intralinkages. In order to obtain lignin monomers in high yield, stabilization of the fragments after their release from the biomass is necessary. Entries 7 and 8 demonstrate the importance of stabilisation of the intermediates in the one-pot LFP approach. In this case, the lignin fragments extracted from oak sawdust are rapidly depolymerised by the combined action of a hydrogenolysis catalyst and an acid catalyst. ${ }^{22}$ The reactive intermediates are stabilized by $\mathrm{Pd} / \mathrm{C}$ catalyst through hydrogenation. Therefore, repolymerization reactions of the fragments and monomers are suppressed. This explains why the monomer yields in the one-pot approach (35 wt\% and $34 \mathrm{wt} \%$ using $\mathrm{H}_{2} \mathrm{SO}_{4}$ and $\mathrm{Al}(\mathrm{OTf})_{3}$, respectively) are higher than those obtained in the two-step approach.

The two-step approach has significant advantages because it allows recovery of the solid catalyst and continuous operation of the hydrogenolysis reaction. The trade-off is that the lignin monomer yield is slightly decreased. Still, this two-step conversion of the solubilized lignin fragments delivered higher monomer yield than the those obtained from depolymerization of organosolv lignin, which typically delivers less than $15 \%$ monomer yield under similar conditions. ${ }^{32}$

\section{Influence acid on delignification}

In the plant cell wall, phenyl glycoside, benzyl ether and $\gamma$-ester bonds are the typical lignin-carbohydrate interlinkages. ${ }^{33}$ In order to determine the impact of acid on delignification, we chose phenyl glycoside (PG) and glyceryl trioleate (GT) as model compounds representing these lignin-carbohydrate bonds. The product yield is shown in Figure 1. Solvolysis of PG and GT is very limited under the applied reaction conditions $\left(160{ }^{\circ} \mathrm{C}, 2 \mathrm{~h}\right)$. The conversion of PG and GT is mainly due to trans-etherification and trans-esterification. ${ }^{34,35}$ Addition of acid catalysts strongly increases the phenol yield (95-100 mol\%), indicating that all tested acids are effective in cleaving the ether linkages in PG. For the $\mathrm{GT}$ model compounds, $\mathrm{H}_{2} \mathrm{SO}_{4}$ and $p$ - $\mathrm{TsOH}$ are very active in cleaving ester bonds, leading to high GT conversion. A lower GT conversion is obtained with $\mathrm{HCl}$ and $\mathrm{H}_{3} \mathrm{PO}_{4}$. These differences in the ability of acids to decompose the linkages in the model compounds are consistent with the trends in lignin delignification. $\mathrm{H}_{2} \mathrm{SO}_{4}$ shows the highest performance on catalysing the cleavage of the ester and ether bonds between lignin and carbohydrate. The efficient cleavage of the lignin-carbohydrate bond is required for lignin extraction and valorization. However, the released sugars might be further converted to furfurals which are involved in the repolymerization by lignin-furfural condensation. ${ }^{30}$

\section{Influence of acid on lignin repolymerization}

Based on the catalytic results in Table 1, we found that a higher degree of delignification in the first delignification step is accompanied by a lower yield of monomer in the second hydrogenolysis step. We surmise that this is due to repolymerization of the lignin fragments during the delignification step. With the aim to gain more insight into this aspect, GPC was applied to characterize the molecular weight $(\mathrm{Mw})$ distribution of the lignin oils from the first

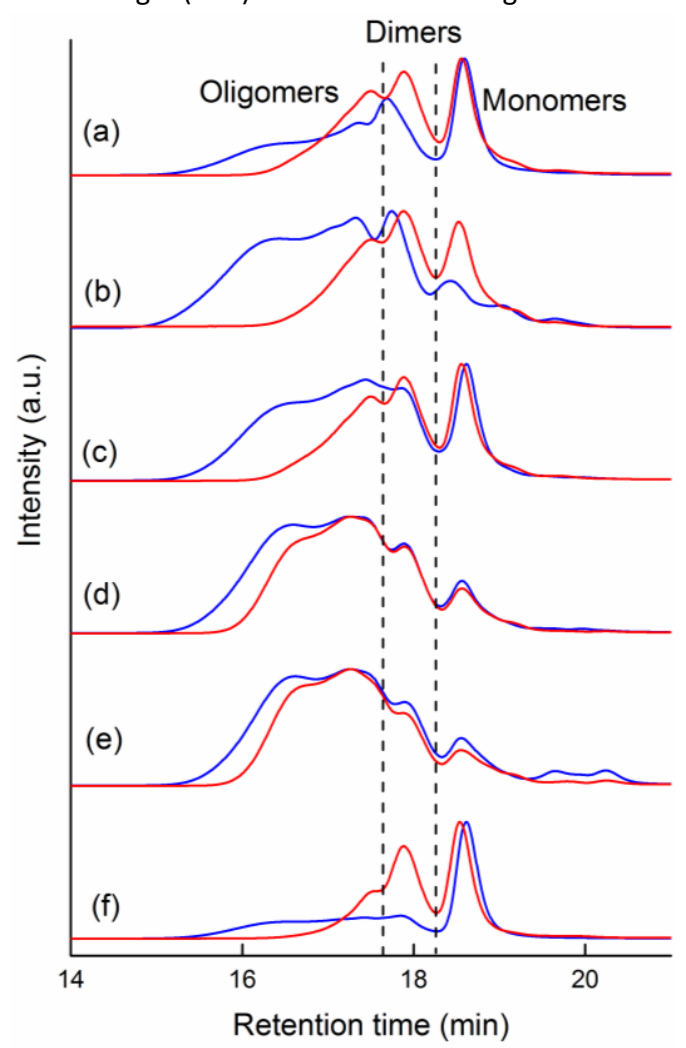

Figure 2 GPC analysis of lignin oils obtained from the first delignification step (blue curve), and the second hydrogenolysis step (red curve) with (a) $\mathrm{H}_{3} \mathrm{PO}_{4}$, (b) $\mathrm{HCl}$, (c) $p$-TsOH, (d) Al(OTf) $)_{3}$, (e) $\mathrm{H}_{2} \mathrm{SO}_{4}$ and (f) without acid. 
delignification step and the second hydrogenolysis step (Figure 2). After the first delignification step, high $\mathrm{Mw}$ oligomers are predominant in the lignin oils in all experiments. Reductive depolymerization of the lignin oil obtained from no-acid delignification only result in a slight decrease of Mw. In contrast, significant $\mathrm{Mw}$ reduction is achieved in the second depolymerization step for the oils from catalytic delignification with $p$-TsOH, $\mathrm{HCl}$ and $\mathrm{H}_{3} \mathrm{PO}_{4}$ acids, which is in line with the higher lignin monomer yields (Table 1 entries 4-6). Depolymerization occurred to a lesser extent for the lignin oils obtained from delignification with $\mathrm{H}_{2} \mathrm{SO}_{4}$ and $\mathrm{Al}(\mathrm{OTf})_{3}$ acids which are also in line with the lower lignin monomer yields (Table 1 entries 2-3).
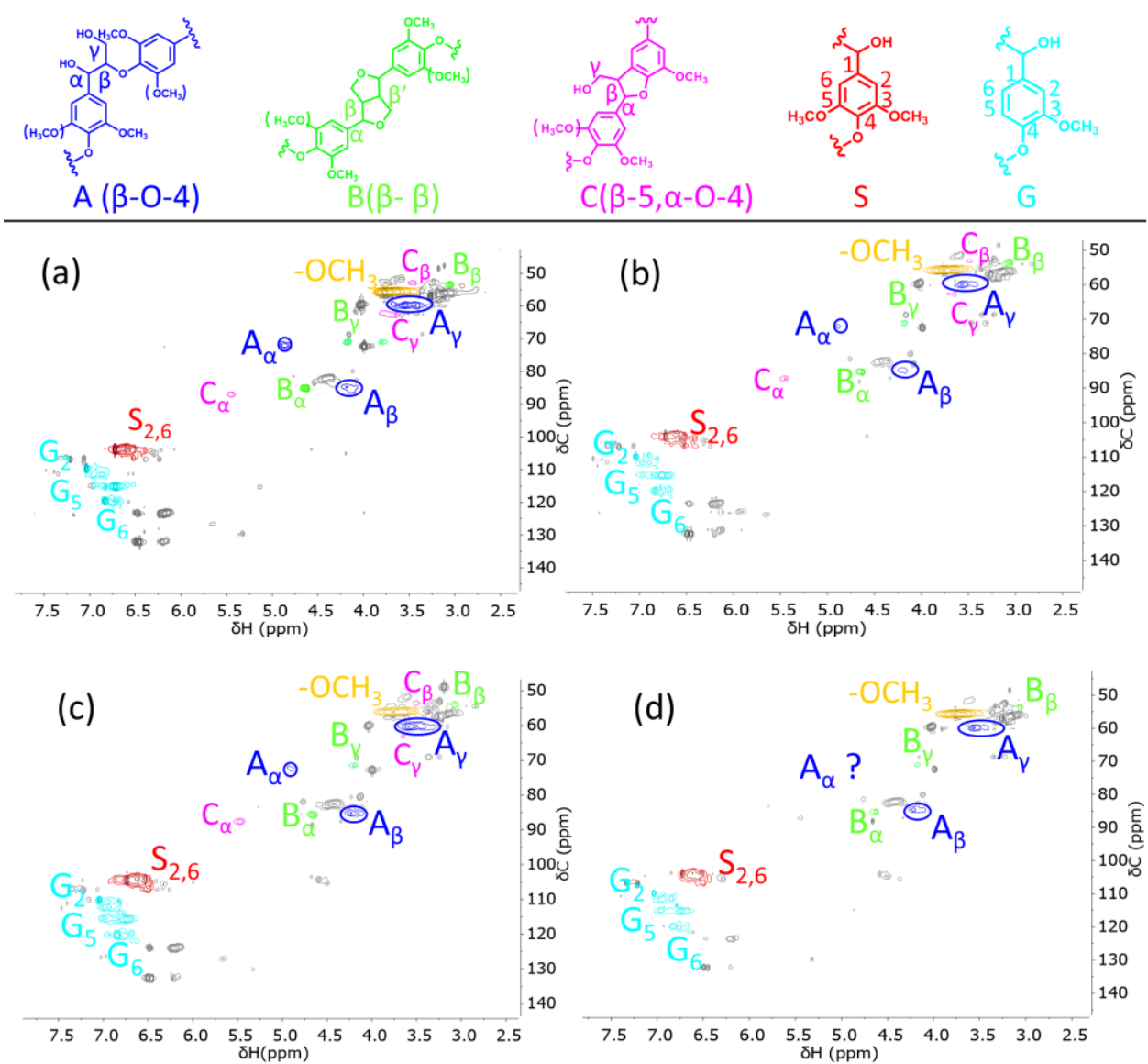

(d)
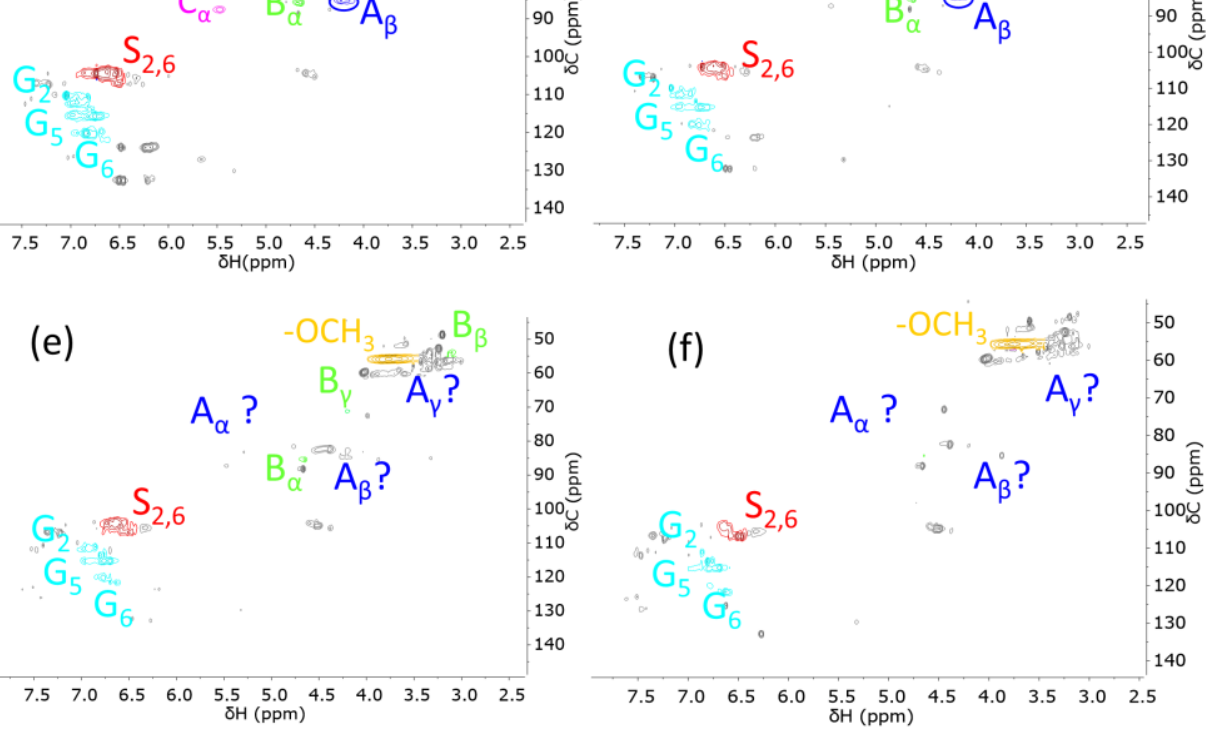

Figure $3 \mathrm{HSQC} N M R$ analysis of lignin oil obtained from delignification (a) without acid, (b) $\mathrm{H}_{3} \mathrm{PO}_{4}$, (c) $\mathrm{HCl}$, (d) $p$ - $\mathrm{TsOH}$, (e) $\mathrm{Al}(\mathrm{OTf})_{3}$, (f) $\mathrm{H}_{2} \mathrm{SO}_{4}$ of oak sawdust in methanol at $160^{\circ} \mathrm{C}$ for $2 \mathrm{~h}$.

We further characterized these lignin oils by 2D HSQC NMR (Figure 3 ) in order to better understand the structural changes of the lignin during acid-catalyzed delignification. In the aromatic region of the $2 \mathrm{D}$ HSQC NMR spectra $\left(\delta_{\mathrm{C}} / \delta_{\mathrm{H}} 100-140 \mathrm{ppm} / 6.0-7.5 \mathrm{ppm}\right)$, the crosssignals show that the lignin oil from oak sawdust mainly consists of syringyl (S) and guaiacyl (G) units, which is a typical feature of hard wood. In the side-chain region $\left(\delta_{C} / \delta_{H} 50-90 \mathrm{ppm} / 2.5-6.0 \mathrm{ppm}\right)$, the signature of the main lignin-lignin intra-linkages $\left(\beta-0-4, \beta-\beta^{\prime}, \alpha-0-4\right.$ , $\beta-5$ ) can be observed for the lignin oil obtained by delignification in pure methanol (Figure $3 a)$. In the no-acid case, the cross-signals of $C_{\alpha}-H_{\alpha}\left(A_{\alpha}\right), C_{\beta}-H_{\beta}\left(A_{\beta}\right)$ and $C_{\gamma}-H_{\gamma}\left(A_{\gamma}\right)$ related to the $\beta-0-4$ intralinkage can be clearly observed (Fig 3a). These cross-signals are much weaker 
when the delignification is catalyzed by $\mathrm{H}_{3} \mathrm{PO}_{4}, \mathrm{HCl}$ and $p$ - $\mathrm{TsOH}$ acids. Specifically, cross-signals of the $\mathrm{C}_{\alpha}-\mathrm{H}_{\alpha}\left(\delta_{\mathrm{C}} / \delta_{\mathrm{H}}, 71.8 / 4.86 \mathrm{ppm}\right)$ in $\beta-0$ 4 structures disappear, while the $\mathrm{C}_{\beta}-\mathrm{H}_{\beta}$ and $\mathrm{C}_{\gamma}-\mathrm{H}_{\gamma}$ cross-signals can still be observed (Fig 3d). After $\mathrm{H}_{2} \mathrm{SO}_{4}$ and $\mathrm{Al}(\mathrm{OTf})_{3}$ delignification, the $\mathrm{C}_{\alpha}-\mathrm{H}_{\alpha}, \mathrm{C}_{\beta}-\mathrm{H}_{\beta}$ signals of $\beta-\mathrm{O}-4$ intralinkages are invisible in the HSQC spectrum (Fig 3e, 3f). The HSQC NMR analysis provides insight into the changes of the $\beta-0-4$ linkages during delignification. The intensity of the $\beta-0-4$ signals is strongly dependent on the acid used. Solvolysis of $\beta-0-4$ linkages is very limited during delignification in pure methanol. Acidolysis of $\beta-\mathrm{O}-4$ bonds is also limited in $\mathrm{H}_{3} \mathrm{PO}_{4}, \mathrm{HCl}$ and $p$-TsOH. The use of $\mathrm{H}_{2} \mathrm{SO}_{4}$ and $\mathrm{Al}(\mathrm{OTf})_{3}$ results in complete disappearance of the $\beta-0-4$ signals, indicating that most ether bonds have been cleaved during delignification. Combined with the GPC results in Fig. 2 , it shows that the breakdown of $\beta-0-4$ linkage in acidic methanol results in lignin repolymerization.

We explored the reactivity of the $\beta-0-4$ structure in more detail by carrying out experiments with the guaiacylglycerol- $\beta$-guaiacyl ether (GGE) model compound. In order to follow recombination of the reaction products, we performed an experiment at $100{ }^{\circ} \mathrm{C}$. The $\mathrm{C}-\mathrm{H}$ cross-signals of the $\beta-0-4$ linkages in GGE are presented in Figure 4. The $\mathrm{C}-\mathrm{H}$ correlation signals of $\beta-\mathrm{O}-4$ structure remain clearly visible, when the reaction is carried out without acid and with $\mathrm{H}_{3} \mathrm{PO}_{4}$. This result is consistent with the data in Figure $3 \mathrm{a}$ and $3 \mathrm{~b}$. Using $\mathrm{H}_{2} \mathrm{SO}_{4}$ and $\mathrm{Al}(\mathrm{OTf})_{3}$ for low temperature delignification, the $\beta-\mathrm{O}-4$ signals are different. These treatments result in the complete removal of the $\mathrm{C}_{\alpha}-\mathrm{H}_{\alpha}$ signal. We observe new cross-signals in the $\delta_{\mathrm{c}} / \delta_{\mathrm{H}} 54-58 / 3.0-$ 3.2 region, which can be related to the formation of new $\mathrm{C}-\mathrm{C}$ bonds. ${ }^{36}$ According to the literature, the formation of new $\mathrm{C}-\mathrm{C}$ linkages in acidic conditions can occur via two mechanisms. First, $\beta$ -

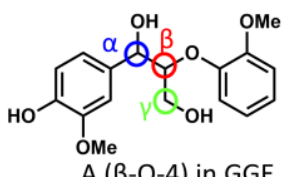

$A(\beta-O-4)$ in GGE

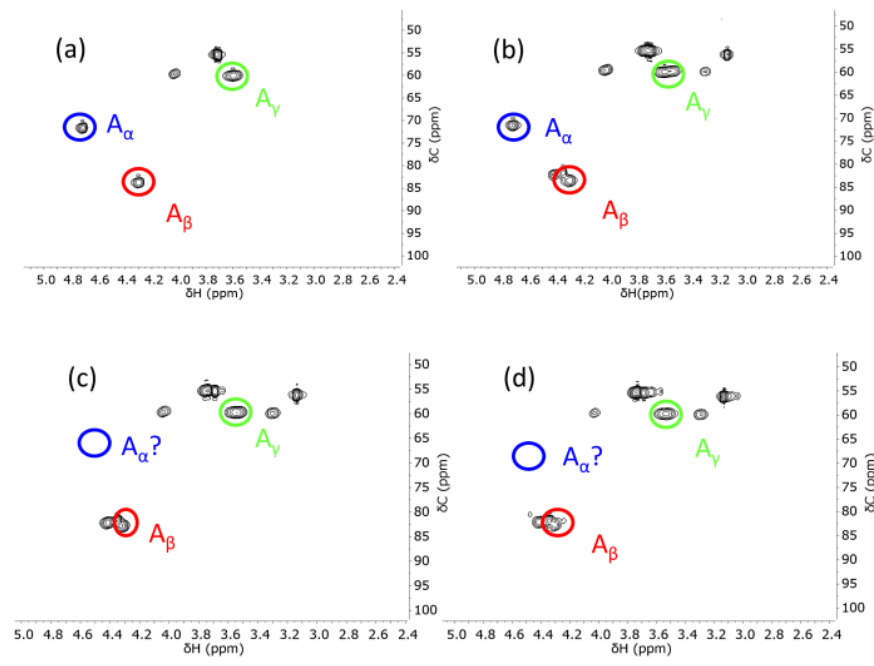

Figure $4 \mathrm{HSQC}$ analysis of structural modification of GGE in (a) no acid addition, (b) $\mathrm{H}_{3} \mathrm{PO}_{4}$, (c) $\mathrm{Al}(\mathrm{OTf})_{3}$, (d) $\mathrm{H}_{2} \mathrm{SO}_{4}$ methanol at $100{ }^{\circ} \mathrm{C}$ for $2 \mathrm{~h}$.
O-4 linked dimers without methoxy groups (1-phenyl-2-phenoxy-1,3propanediol and 1- (4-hydroxyphenyl)-2-phenoxy-1,3-propanediol) are prone to form self-condensation products through intramolecular condensation. The presence of methoxy groups in $\mathrm{G} / \mathrm{S}$ units can effectively limit this type of repolymerization. ${ }^{37}$ Second, protonation of hydroxyl groups located at the $\alpha$ position $\left(A_{\alpha}\right)$ is followed by dehydration to form the benzylic cation intermediates, which can react with aromatic monomers to form new $\mathrm{C}-\mathrm{C}$ bonds. The exact structure of the resulting structures could not be resolved here. Based on the HSQC NMR, it can be concluded that the removal of $\mathrm{C}_{\alpha}-\mathrm{H}_{\alpha}$ signal shows that the latter mechanism is predominant as a cause of recondensation in the present study.

It has also been shown that breakdown of $\beta-0-4$ linkage results in lignin monomers with ketone and aldehyde groups in acidic condition. ${ }^{20,38}$ We selected hydrocinnamaldehyde as a presentative model compound to confirm the stability of an aldehyde group in (acidic) methanol. Figure 5 shows the GPC chromatogram of the mixtures after reaction at $160{ }^{\circ} \mathrm{C}$ for $2 \mathrm{~h}$. With $\mathrm{H}_{2} \mathrm{SO}_{4}$ and $\mathrm{Al}(\mathrm{OTf})_{3}$, higher $\mathrm{Mw}$ products are formed. These reactions occur at a lower rate in the presence of $\mathrm{H}_{3} \mathrm{PO}_{4}$. Even in the absence of acid, some hydrocinnamaldehyde reacts to heavier products. On the contrary, the $\mathrm{Mw}$ of hydrocinnamaldehyde remains unchanged after acidolysis in $\mathrm{H}_{2} \mathrm{SO}_{4}$ in the presence of $\mathrm{Pd} / \mathrm{C}$ in an atmosphere of 30 bar $\mathrm{H}_{2}$. This result clearly shows that saturation of the aldehyde group avoids condensation of cinnamaldehyde to heavier products. Together these results can well explain the higher lignin monomer yield

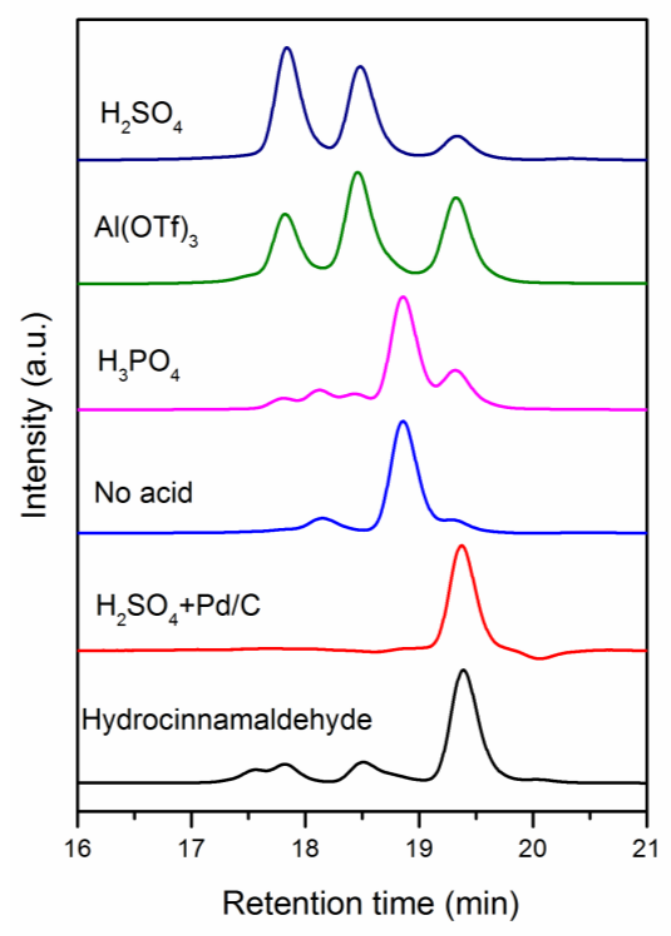

Figure $5 \mathrm{GPC}$ chromatograms of reaction mixtures obtained from hydrocinnamaldehyde in methanol at $160^{\circ} \mathrm{C}$ for $2 \mathrm{~h}$ under varying catalysts. 


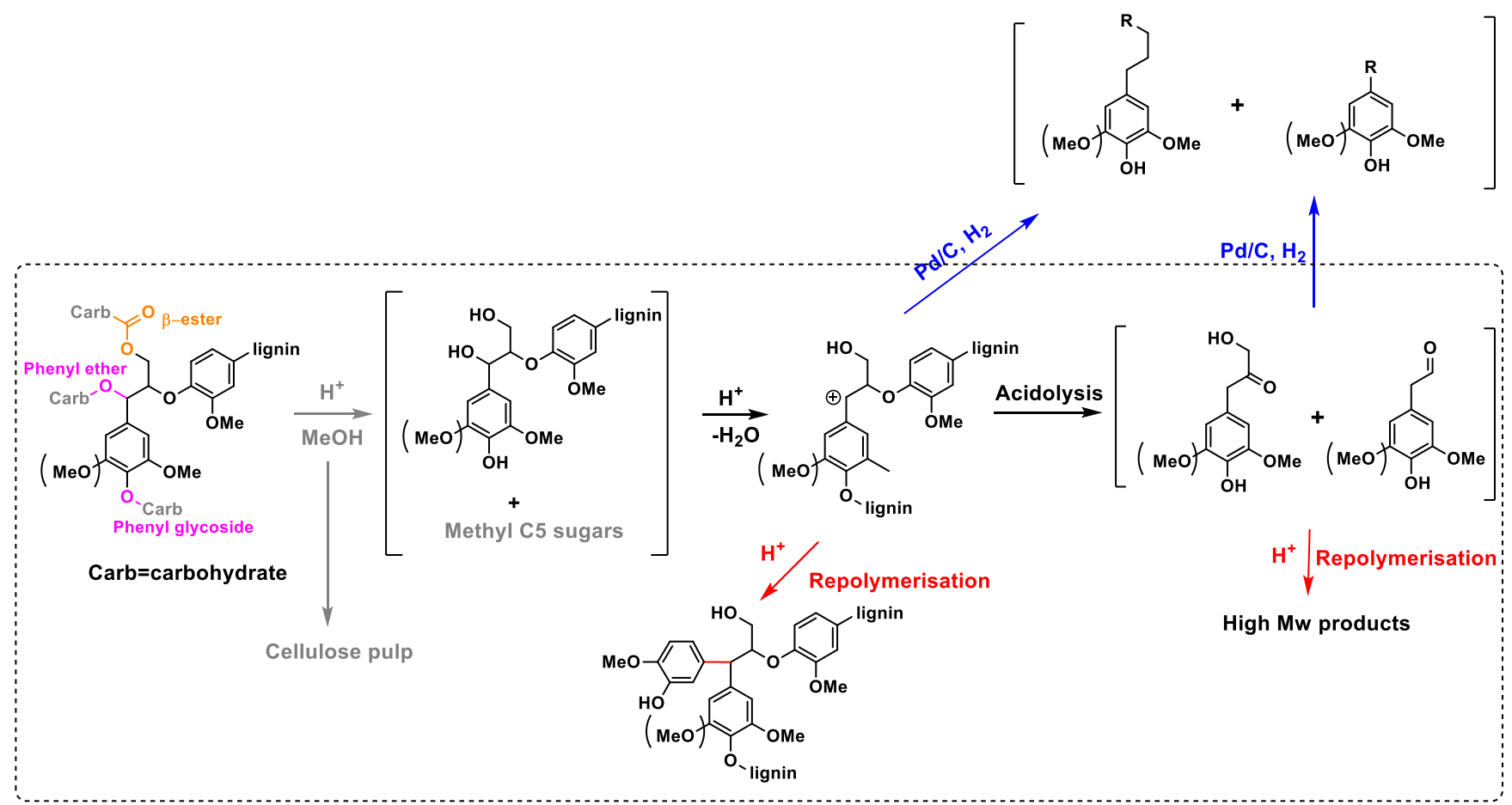

Figure 6 The roles of acid on lignin conversion in the methanol: delignification (gray), lignin depolymerization (black) and lignin repolymerization (red). Catalytic stabilisation of active intermediates over $\mathrm{Pd} / \mathrm{C}$ (blue) is important to prevent repolymerization.

obtained with oak sawdust in the one-step LFP approach (Entries 7 8, Table 1).

Overall, the above experiments provide a deeper insight of the impact of different acids on the fate of lignin in the one- and two-step LFP conversion of lignocellulosic biomass. A tentative reaction scheme is depicted in Figure 6 . Acids act as catalysts in the cleavage of ester/ether lignin-carbohydrate interlinkages, resulting in the release of lignin fragments in the methanol solvent. The use of $\mathrm{H}_{2} \mathrm{SO}_{4}$ and $\mathrm{Al}(\mathrm{OTf})_{3}$ also catalyze the cleavage of ether bonds in lignin. The dehydration of the $\alpha-\mathrm{OH}$ group of the $\beta-0-4$ structure results in reactive carbocationic intermediates that are involved in repolymerization reactions. Besides, high $\mathrm{Mw}$ compounds can also be formed due to condensation reactions between unsaturated monomers. These reactions lead to theformation of new C-C bonds, which cannot be depolymerized in the second mild hydrogenolysis step anymore. To obtain a good delignification degree and a high monomer yield, in situ stabilisation of reactive species is required. Adding formaldehyde during acidic delignification can stabilize the reactive benzylic cation intermediates by forming a 1,3-dioxane structure. ${ }^{27}$ The unstable aldehyde can also be reacted with diols. ${ }^{39}$ Another approach is to rapidly hydrogenate the reactive intermediates during delignification, which essentially represents the one-step LFP approach. Considering the results above, the use of a weak acid like $\mathrm{H}_{3} \mathrm{PO}_{4}$ is suitable in a two-step LFP approach.

\section{Stability of $\mathrm{Pd} / \mathrm{C}$}

Catalyst stability is important to the development of an industrial application. Especially, the stability of a heterogeneous metal catalyst used in liquid phase reactions can be problematic. Deactivation can be due to leaching of the active metal, sintering, poisoning, and attrition. ${ }^{40,41}$ Usually, catalyst deactivation is caused by several factors, making it a complex matter to study. We investigated the changes with respect to $\mathrm{Pd}$ loading and particle size of the $\mathrm{Pd} / \mathrm{C}$ catalyst by carrying out blank experiments in which $\mathrm{Pd} / \mathrm{C}$ was heated in methanol and different acids to $180^{\circ} \mathrm{C}$ for $2 \mathrm{~h}$.

Table 2 shows the $\mathrm{Pd}$ recovery and particle size after treatments with different acid catalysts. The $\mathrm{Pd}$ metal recovery is determined by ICP analysis of the fresh and spent catalyst. In the acid-free case, $96 \%$ of the Pd metal can be recovered (Table 2 entry 1 ). Similar degrees of $\mathrm{Pd}$ metal recovery are observed when the reaction is carried out in $\mathrm{H}_{2} \mathrm{SO}_{4}$ and $\mathrm{Al}(\mathrm{OTf})_{3}$ (Table 2

Table 2 Results of Pd recovery and Pd particle size in different acid catalysts

\begin{tabular}{cccc}
\hline Entry & $\begin{array}{c}\text { Acid } \\
\text { catalyst }\end{array}$ & Pd recovery (\%) ${ }^{\text {a }}$ & Pd particle size $(\mathrm{nm})^{\mathrm{b}}$ \\
\hline 1 & $\mathrm{No} \mathrm{acid}_{2}$ & 96 & $3.9 \pm 1.4$ \\
3 & $\mathrm{H}_{2} \mathrm{SO}_{4}$ & 97 & $3.7 \pm 1.6$ \\
4 & $\mathrm{Al}(\mathrm{OTf})_{3}$ & 97 & $3.4 \pm 2.3$ \\
5 & $p-\mathrm{TsOH}$ & 85 & $3.8 \pm 1.8$ \\
6 & $\mathrm{HCl}$ & 78 & $29 \pm 14$ \\
\hline
\end{tabular}

a $\mathrm{Pd}$ recovery is determined by the $\mathrm{Pd}$ concentration measured by ICP b Pd particle size is calculated by the average of $c a .200 \mathrm{Pd}$ particles in TEM images 


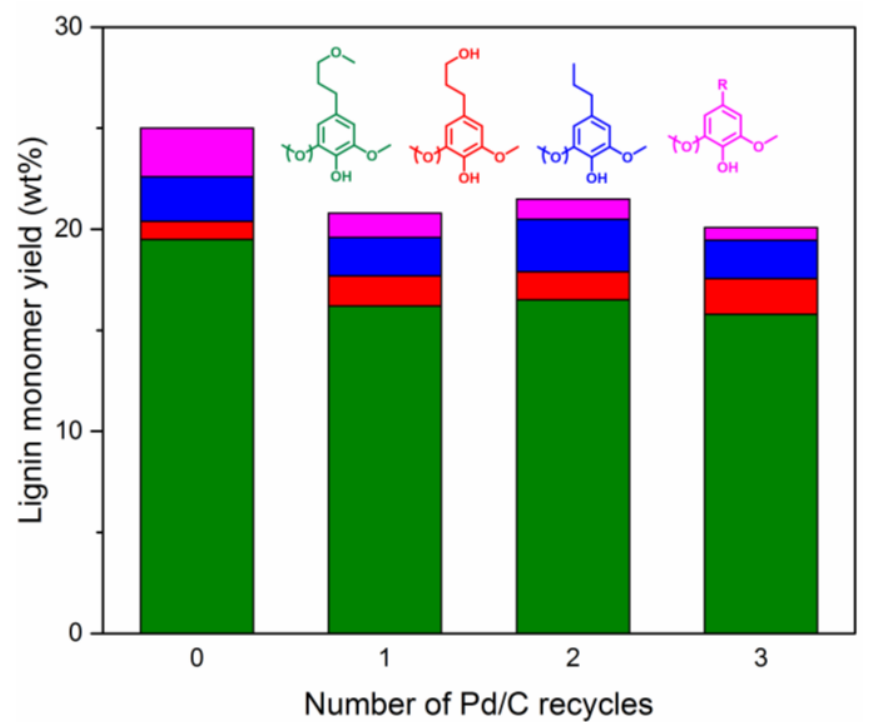

Figure 7 Results of recyclability test of $\mathrm{Pd} / \mathrm{C}$ catalyst.

entry 2-3). This indicates that $\mathrm{Pd} / \mathrm{C}$ is stable in the presence of small amounts of $\mathrm{H}_{2} \mathrm{SO}_{4}$ and $\mathrm{Al}(\mathrm{OTf})_{3}$. Reaction with $p$-TsOH and $\mathrm{HCl}$ results in $85 \%$ and $78 \% \mathrm{Pd}$ recovery, indicative of partial dissolution of $\mathrm{Pd} / \mathrm{C}$ (Table 2 entry 4-5). An interesting finding is that the recovery (92\%) of $\mathrm{H}_{3} \mathrm{PO}_{4}$-treated $\mathrm{Pd} / \mathrm{C}$ is lower than in $\mathrm{H}_{2} \mathrm{SO}_{4}$-treated sample. Along with the recovery, the particle size distribution of $\mathrm{Pd}$ nanoparticles is also influenced by the acidic environments. The average $\mathrm{Pd}$ particle sizes of the spent catalysts remain unchanged in the $\mathrm{H}_{2} \mathrm{SO}_{4}, \mathrm{Al}(\mathrm{OTf})_{3}, p$-TsOH and $\mathrm{H}_{3} \mathrm{PO}_{4}$ experiments. Only the use of $\mathrm{HCl}$ results in a substantial growth of the $\mathrm{Pd}$ nanoparticles. Overall, this study shows that the use of $\mathrm{HCl}$ is the least attractive with respect to catalyst stability, despite it providing the highest lignin monomer yield in the two-step process (Table 1, entry 5).

The recycle of $\mathrm{Pd} / \mathrm{C}$ catalyst is facile in the two-step process due to separation of delignification and lignin depolymerization. Based on the lignin monomer yield and carbohydrate retention, $\mathrm{H}_{3} \mathrm{PO}_{4}$ acid is suitable for the present two-step process. The recycle of $\mathrm{Pd} / \mathrm{C}$ catalyst was performed in the presence of $\mathrm{H}_{3} \mathrm{PO}_{4}$ acid to assess the stability of $\mathrm{Pd} / \mathrm{C}$ (Figure 7). The sign of deactivation was only observed in the first recycle, shown that the lignin monomer yield slightly decreased from $25.0 \%$ to $20.9 \%$. The cause of lower yield could be the small amount of $\mathrm{Pd}$ metal leaching as indicated in entry 6, Table 2. The Pd/C catalyst shows good stability for the further recycles. The lignin monomer yields were $21.6 \%$ and $20.1 \%$ in second and third recycle. No significant loss of catalytic activity and selectivity was observed, demonstrating the good stability of $\mathrm{Pd} / \mathrm{C}$ in the presence of $\mathrm{H}_{3} \mathrm{PO}_{4}$ acid.

\section{Conversion of carbohydrate pulps to glucose}

Efficient saccharification of cellulose to glucose is the first step required for cellulose valorization. For the acid hydrolysis of cellulose, strong acids are usually employed at relatively high temperature. Another approach is to use enzymatic hydrolysis, which can be carried out at milder conditions. Typically,
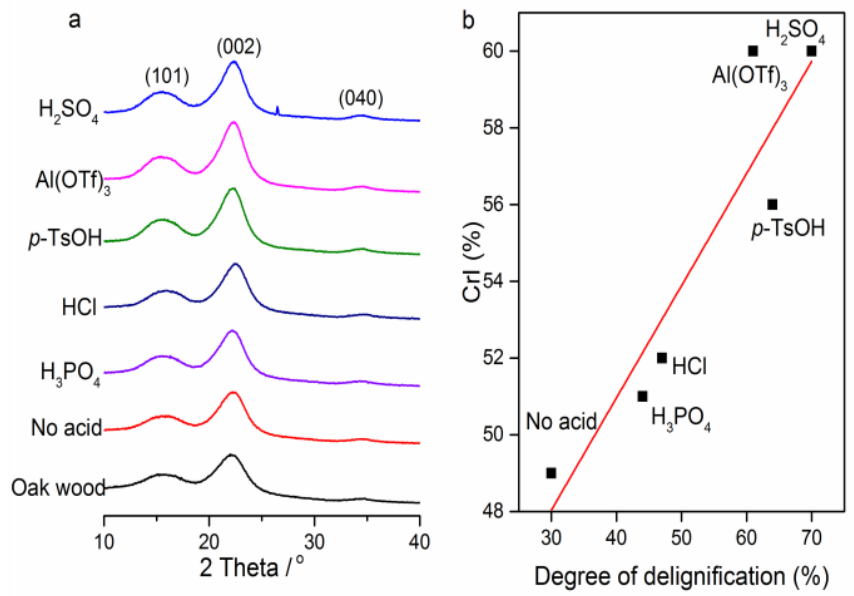

Figure 8 XRD patterns of (a) oak sawdust and cellulose pulps obtained and ( $b$ ) the relationship between delignification degree and cellulose crystallinity.

cellulose is resistant to enzymatic digestion, because the presence of lignin makes cellulose less accessible to enzymes. ${ }^{42}$ The carbohydrate pulps obtained from the two-step process are suitable substrates for enzymatic hydrolysis because of the good delignification degree and high C6-sugar retention. In the context of lignin valorization, we therefore explored the conversion of carbohydrate pulps derived in the two-step LFP approach by enzymatic hydrolysis to demonstrate its potentials for bioenergy production.

Structural features, such as crystallinity, morphology and lignin content, are important to assess the suitability of cellulose towards enzymatic hydrolysis. ${ }^{43,44}$. The XRD spectrum obtained for the dignified samples are shown in Figure 8a. The reflections at $2 \theta=16^{\circ}, 22^{\circ}$ and $34^{\circ}$ observed in all samples are characteristic of cellulose I. Untreated oak sawdust has the lowest crystallinity of $42 \%$. Generally, the crystallinity of cellulose shows a linear correlation with the degree of delignification (Figure $8 b$ ). The pulp obtained without using an acid catalyst shows a higher crystallinity (49\%) than the untreated oak sawdust. The use of acid catalysts in first step significantly increases the crystallinity of the pulps due to a better removal of amorphous components such as lignin and hemicellulose.

The morphology of cellulose pulp is visualized by SEM (Figure 9). The untreated oak sawdust shows a highly intact structure (Figure 9a). The morphology of oak sawdust remains unchanged after delignification with pure methanol (Figure 9b). A clear distinction can be made between pulps delignified with and without acid. When acids are used, a porous structure is apparent on the surface of the cellulose pulp (Figure 9c-d), which is caused by lignin removal. A fibrous surface morphology is observed for the cellulose pulp obtained using $\mathrm{H}_{2} \mathrm{SO}_{4}, \mathrm{Al}(\mathrm{OTf})_{3}$ and $p$ - $\mathrm{TsOH}$ in the delignification step, indicating that these pulps are less spatially surrounded by lignin (Figure $9 \mathrm{e}-\mathrm{g}$ ). A rough surface and some agglomeration can still be observed at the edges of the fibres. This is usually caused by lignin droplets, which are formed by repolymerization and relocation in the delignification process. 45 

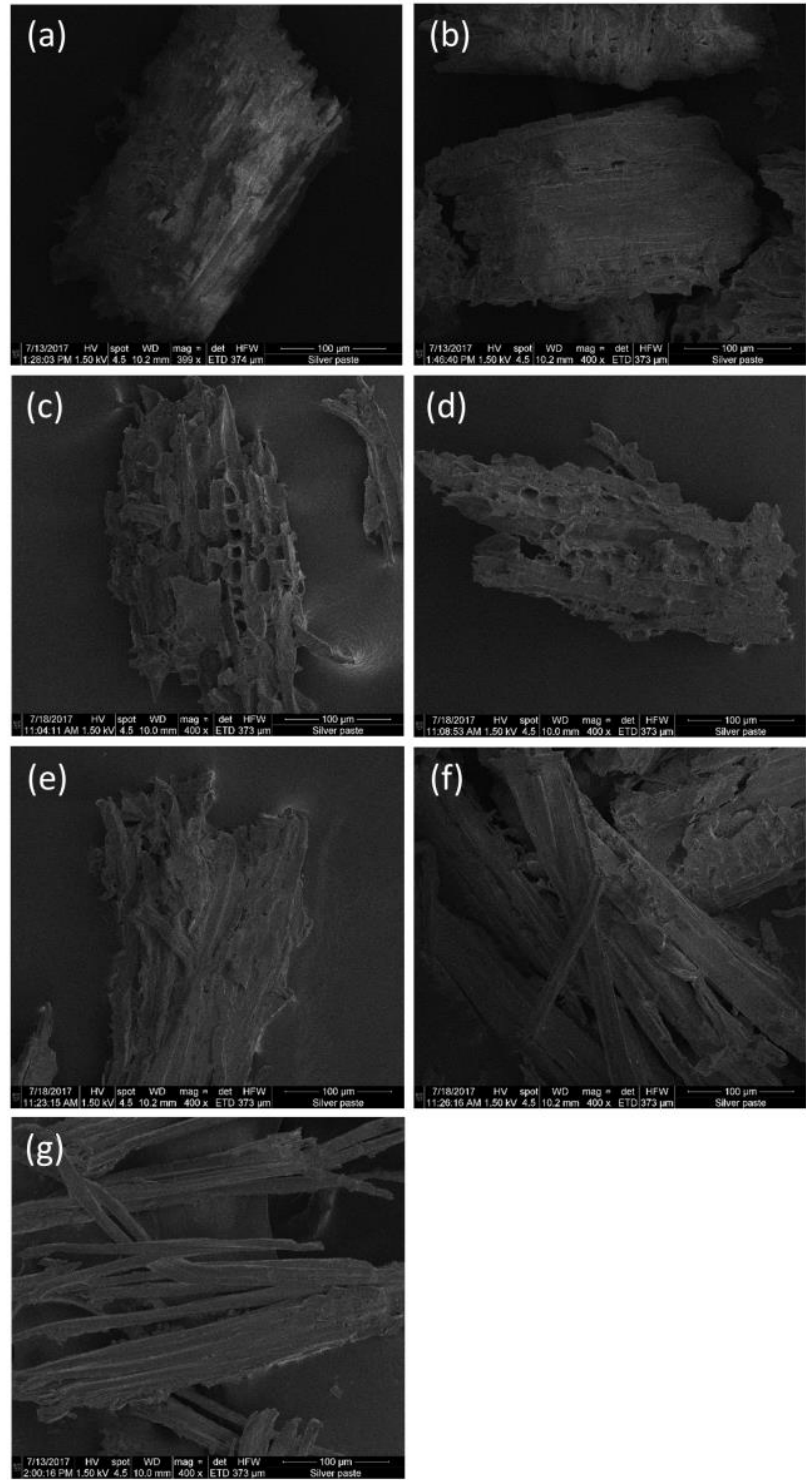

Figure 9 SEM images of (a) oak sawdust and cellulose pulp obtained (b) without acid, or using as acid catalysts (c) $\mathrm{H}_{3} \mathrm{PO}_{4}$, (d) $\mathrm{HCl}$, (e) $p$ $\mathrm{TsOH}$, (f) Al(OTf) $)_{3}$ and (g) $\mathrm{H}_{2} \mathrm{SO}_{4}$ at $160{ }^{\circ} \mathrm{C}$ for $2 \mathrm{~h}$.

The results of enzymatic hydrolysis of the cellulose pulps are shown in Figure 10. Reported glucose yields are based on the amount of glucose in the pulp analysed by sulfuric acid hydrolysis. Untreated oak sawdust shows a very high resistance to enzymatic hydrolysis and only $8 \%$ of glucose is obtained. After methanol delignification, the glucose yield is improved to $31 \%$. It is clear from Figure 10 that the use of acid catalysts in the delignification step result in a significant improvement of the glucose yield. After $72 \mathrm{~h}$ of enzymatic hydrolysis, the pulp derived from $\mathrm{H}_{2} \mathrm{SO}_{4}$ delignification shows the highest yield of glucose (76\%).

The enzymatic digestion of cellulose pulp can be affected by the enzyme activity and substrate suitability. The substrate-related factors typically are crystallinity, morphology, delignification degree, etc. For a pure cellulose substrate, a low-crystallinity

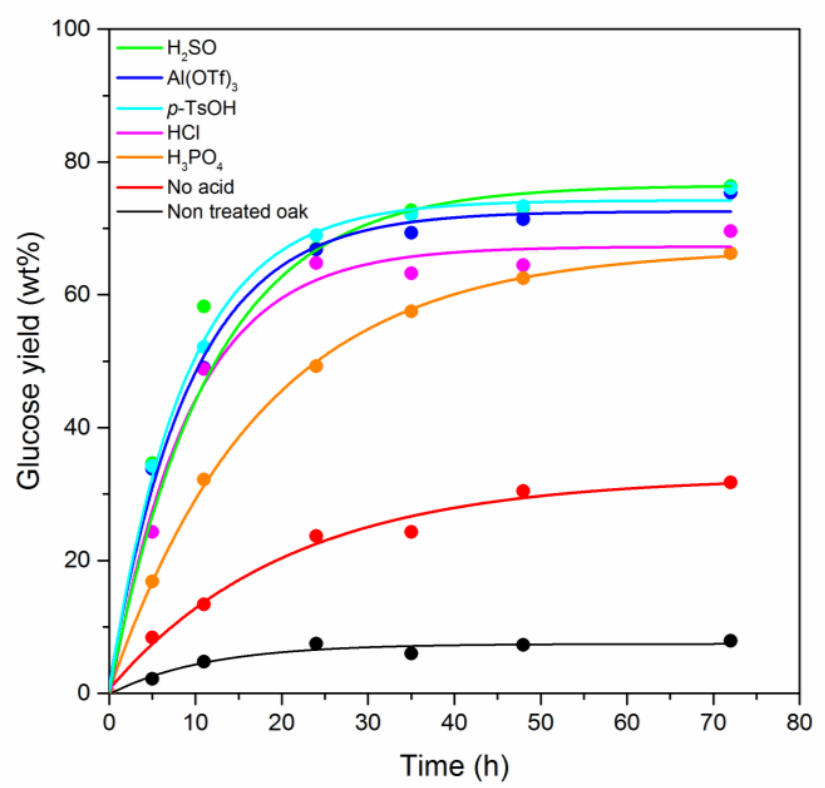

Figure 10 Glucose yield from enzymatic hydrolysis of oak sawdust and delignified cellulose pulps.

sample shows a faster rate because the amorphous domains in cellulose are first hydrolysed. ${ }^{46}$ In the present study, we show that pulps with a higher crystallinity are converted faster. This is an apparent effect as the higher crystallinity stems from a higher degree of delignification. Therefore, we infer that the saccharification of the pulps is mainly influenced by the lignin content. In addition, delignification also leads to a fibrous surface of the pulps (Figure 9). A better accessibility of the surface is created and more cellulose is exposed to the enzyme catalyst. Consequently, a higher rate and a higher glucose yield can be obtained by enzymatic hydrolysis of pulps obtained from acid delignification. The glucose yield shows a positive correlation with the delignification degree, decreasing in the order $\mathrm{H}_{2} \mathrm{SO}_{4}>p$-TsOH $>\mathrm{Al}(\mathrm{OTf})_{3}>\mathrm{HCl}>\mathrm{H}_{3} \mathrm{PO}_{4}>$ no acid $>$ untreated oak sawdust.

\section{Conclusions}

A two-step catalytic biorefinery process is presented to isolate and convert lignin from woody biomass into aromatics. The first step demonstrates that the delignification degree and sugar retention strongly depend on the use of acids, in which sulfuric acid shows the best performance. Reductive depolymerization of the resulting lignin oils in the second step indicates that a high degree of delignification results in a low aromatics monomer yield. The use of strong acids effectively improves the delignification degree through the cleavage of lignin-carbohydrate (ester and ether) bonds, but it also results in lignin repolymerization. These acids catalyze lignin repolymerization due to formation of reactive intermediates such as the benzylic cation and unsaturated monomers. The stabilization of lignin intermediates through hydrogenation is essential to obtain a high monomeric yield. The stability of $\mathrm{Pd} / \mathrm{C}$ is seriously affected by $\mathrm{HCl}$ due to leaching and sintering. The delignified pulps retained abundant $\mathrm{C} 6$ sugars, which can be converted to glucose with high yield through enzymatic hydrolysis. $\mathrm{H}_{3} \mathrm{PO}_{4}$ is the most suitable acid 
catalyst for the present two-step process based on the results of delignification, phenolic monomer yield, lignin repolymerization, carbohydrate conversion and $\mathrm{Pd} / \mathrm{C}$ stability. Overall, the two-step process provides a simple, efficient way to isolate and convert lignin contained in a lignocellulose matrix into phenolic monomers with good yield, whilst allowing to recycle the heterogeneous catalyst and yield a cellulose pulp amenable to enzymatic saccharification.

\section{Experimental}

Oak wood sawdust was obtained from Houtzagerij Mennen (SintOedenrode, the Netherlands). $\mathrm{H}_{3} \mathrm{PO}_{4}(85 \%)$, Al(OTf) 3 (99\%), $p$-TsOH (98.5\%), phenyl glycoside (PG, 97\%), glyceryl trioleate (GT, 97\%), hydrocinnamaldehyde (95\%), cellulase (Cellic CTec2), citric acid, disodium phosphate and $5 \mathrm{wt} \% \mathrm{Pd} / \mathrm{C}$ were purchased from Sigma Aldrich. $\mathrm{HCl}$ (37 wt\% in water) and $\mathrm{H}_{2} \mathrm{SO}_{4}$ (95-97\%) and anhydrous methanol, ethyl acetate, THF and $d_{6}$-DMSO were purchased from Merck. n-dodecane was purchased from Alfa Aesar. Guaiacylglycerol- $\beta$-guaiacyl ether (GGE, 97\%) was purchased from $\mathrm{TCl}$.

Oak sawdust was sieved to a particle size of $125-300 \mu \mathrm{m}$. The sawdust was pre-treated to remove the extractives by water $(24 \mathrm{~h})$ and ethanol $(24 \mathrm{~h})$ in a Soxhlet extractor. After extraction, the oak sawdust was dried at $105^{\circ} \mathrm{C}$ overnight.

In a typical experiment, $2.0 \mathrm{~g}$ extracted oak sawdust, $40 \mathrm{ml}$ methanol and a certain amount of acid catalyst was introduced into a $100 \mathrm{ml}$ Parr autoclave. The autoclave was sealed and flushed three times with nitrogen to remove air. The mixture was heated to $160{ }^{\circ} \mathrm{C}$ (ca. $10{ }^{\circ} \mathrm{C} \mathrm{min}-1$ ) and the stirring speed was $500 \mathrm{rpm}$. After $2 \mathrm{~h}$ acid delignification, the autoclave was cooled to room temperature in an ice bath. The extracted lignin oil and cellulose pulp were separated by filtration. In the hydrogenolysis step, the filtrate, $100 \mathrm{mg} \mathrm{Pd} / \mathrm{C}$ and $30 \mu \mathrm{l}$-dodecane were mixed in the autoclave. After flushing the autoclave with nitrogen, it was pressurized with $\mathrm{H}_{2}$ to 30 bar. After a leak check, the reaction mixture was heated to $180^{\circ} \mathrm{C}$ (ca. $10^{\circ} \mathrm{C} \mathrm{min}$ 1). The stirring speed was $500 \mathrm{rpm}$. After reaction, the autoclave was cooled in an ice bath and depressurized. Aliquots of the liquid phase were analysed by GC and GC-MS. We determined the following main parameters.

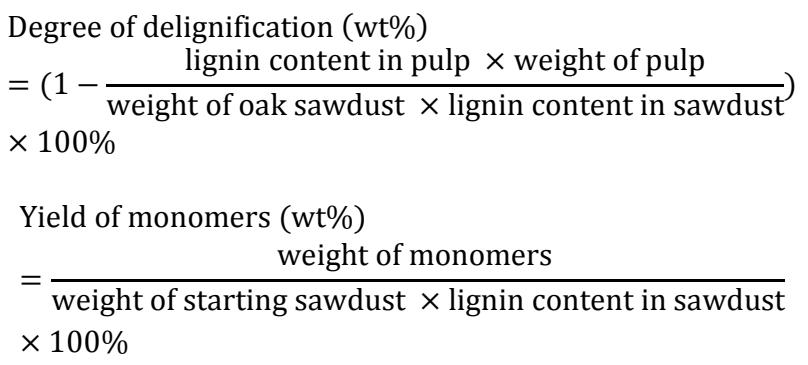

For the GPC and 2D HSQC NMR characterization, methanol was removed by evaporation and the obtained lignin oil was dissolved in THF and $\mathrm{d}_{6}$-DMSO for GPC and 2D HSQC NMR characterization, respectively. GPC analysis was performed by using a Shimadzu apparatus equipped with a UV-Vis detector at $254 \mathrm{~nm}$. The columns are Mixed-C and Mixed-D (polymer laboratories) in series. Analysis was carried out at $25^{\circ} \mathrm{C}$ using THF as eluent at flow rate of $1 \mathrm{ml} / \mathrm{min}$. The 2D HSQC NMR was performed by using a Varian $400 \mathrm{MHz}$ spectrometer. The spectral widths were $5000 \mathrm{~Hz}$ and $20000 \mathrm{~Hz}$ for ${ }^{1} \mathrm{H}$ - and ${ }^{13} \mathrm{C}$ - dimensions. The relaxation time was $1.5 \mathrm{~s}$. The number of scan was 16 and 256 times increments were recorded in the ${ }^{13} \mathrm{C}$ dimension.

The recyclability of $\mathrm{Pd} / \mathrm{C}$ catalyst was tested in the presence of optimized acid catalyst. The spent $\mathrm{Pd} / \mathrm{C}$ catalyst was separated by centrifugation ( $5000 \mathrm{rpm} / \mathrm{min}, 10 \mathrm{~min}$ ) and was washed with $40 \mathrm{ml}$ of pure methanol. For the Pd/C stability test, the spent catalyst, lignin oil and $30 \mu \mathrm{l}$-dodecane were added to the autoclave. The hydrogenolysis of lignin oil was performed under the conditions as mentioned before.

For model compound experiments, a small autoclave with a volume of $12 \mathrm{ml}$ was used. An amount of $50 \mathrm{mg}$ of a model compound, $10 \mu \mathrm{l}$-dodecane, acid co-catalyst and $5 \mathrm{ml}$ methanol were added to the autoclave. The autoclave was flushed by nitrogen and heated to the desired reaction temperature and kept for $2 \mathrm{~h}$. After cooling in an ice bath, the products were analysed by GC, GC-MS, GPC and HSQC 2D NMR. The product yield was calculated in the following way.

$$
\begin{aligned}
& \text { Yield }(\mathrm{mol} \%) \\
& =\frac{\text { moles of monomer }}{\text { moles of model compound }} \\
& \times \frac{\text { reaction stoichiometry of model compound }}{\text { reaction stoichiometry of monomer }} \times 100 \%
\end{aligned}
$$

$\mathrm{Pd} / \mathrm{C}$ was characterized by ICP elemental analysis and TEM. For this purpose, an amount of $100 \mathrm{mg} \mathrm{Pd} / \mathrm{C}, 5 \mathrm{ml}$ methanol and acid were introduced in a small $12 \mathrm{ml}$ autoclave which was pressurized with 30 bar $\mathrm{H}_{2}$ after proper flushing with nitrogen. The temperature for these experiments was $180{ }^{\circ} \mathrm{C}$ and the stirring speed was $500 \mathrm{rpm}$. After $2 \mathrm{~h}$, the autoclave was stopped and the spent catalyst was collected by centrifugation for further analysis. The leaching of $\mathrm{Pd} / \mathrm{C}$ was measured by ICP using the Ametek SPECTRO Spectroblue apparatus. $20 \mathrm{mg}$ of $\mathrm{Pd} / \mathrm{C}$ catalyst was mixed with $20 \mathrm{ml}$ of $3 \mathrm{M} \mathrm{HNO}_{3}$ aqueous solution. To digest the $\mathrm{Pd}$ metal, the solution was stirred and heated to $80^{\circ} \mathrm{C}$ for $1 \mathrm{~h}$. Then the solution was diluted to $50 \mathrm{ml}$ in a $50 \mathrm{ml}$ volumetric flask. The carbon residue was removed by a paper filter. The solution was diluted 10 times and ready for ICP analysis. The Pd particle size was analysed by TEM using a FEI Tecnai transmission electron microscope at the acceleration voltage of $200 \mathrm{kV}$. A small amount of Pd/C catalyst was suspended in pure ethanol. The suspension was dispersed over a Cu grid with a holey carbon film and ready for TEM analysis. The quality of the cellulose pulp was determined by compositional analysis, XRD and SEM. The composition of cellulose pulp was analysed by the standard procedures of NREL. ${ }^{47}$ XRD is performed by a Bruker 2D Phaser. Using $\mathrm{Cu} \mathrm{K \alpha}$ radiation, the detector angle $2 \theta$ is varied from $5^{\circ}$ to $50^{\circ}$ in 2227 steps and a slit of $0.6 \mathrm{~mm}$. Based on the diffraction pattern, the crystallinity index $(\mathrm{Crl})$ is determined by the peak height method. 


$$
\mathrm{CrI}=\frac{I_{002}-I_{A M}}{I_{002}} \times 100 \%
$$

$\mathrm{I}_{002}$ represents the intensity of crystalline peak corresponding to the 002 plane at about $2 \theta=22.5^{\circ} ; I_{A M}$ is the intensity found at the minimum between the 002 peak and the 101 peak. The morphology of cellulose pulp is analysed by the SEM using a FEI Quanta 3D FEG microscope. The accelerating voltage was 1.50 kV.

Enzymatic hydrolysis of cellulose pulp was performed in a $20 \mathrm{ml}$ glass flask under magnetic stirring. An amount of $100 \mathrm{mg}$ cellulose pulp was mixed in a flask with $10 \mathrm{ml}$ citrate buffer $(0.1$ $\mathrm{M}, \mathrm{pH}$ 4.8). The flask was placed in an oil bath of $50{ }^{\circ} \mathrm{C}$. The enzyme (Cellic Ctec 2) loading was $40 \mathrm{FPU} / \mathrm{g}$ cellulose. The hydrolysis was initiated when the proper amount of enzyme was added. $200 \mu \mathrm{m}$ of sample was taken from the mixture and diluted to $1 \mathrm{ml}$ by water. The enzyme was deactivated in boiling water for $10 \mathrm{~min}$. The liquid mixture was filtered for further HPLC analysis. The conditions of HPLC analysis as follows: Column: Rezex TM RPM-Monosaccharide Pb+2 (8\%) (300 x 7.8 $\mathrm{mm}$, Phenomenex Inc.); oven temperature: $80{ }^{\circ} \mathrm{C}$; injection volume: $10 \mu \mathrm{l}$; flow rate: $0.6 \mathrm{ml} / \mathrm{min}$; detector: evaporative light scattering detector; mobile phase: HPLC grade water; run time: 25 mins.

$$
\begin{aligned}
& \text { Yield of glucose }(w t \%) \\
& =\frac{\text { weight of glucose }}{\text { weihght of pulp } \times \text { cellulose content in pulp }} \times 100 \%
\end{aligned}
$$

\section{Conflicts of interest}

There are no conflicts to declare.

\section{Acknowledgements}

The authors would like to thank the China Scholarship Council (CSC) for financial support, A. M. Elemans-Mehring for ICP measurement, Alexey Bolshakov for SEM measurement, Arno van Hoof and Jiadong Zhu for TEM measurement.

\section{References}

1 C. H. Zhou, X. Xia, C. X. Lin, D. S. Tong and J. Beltramini, Chem. Soc. Rev., 2011, 40, 5588-617.

2 M. H. L. Silveira, A. R. C. Morais, A. M. C. Lopes, D. N. Olekszyszen, R. Bogel-Lukasi, J. Andreaus, L. P. Ramos, ChemSusChem, 2015, 8, 3366-3390.

3 D. M. Alonso, S. G. Wettstein and J. A. Dumesic, Chem. Soc. Rev., 2012, 41, 8075-8098.

4 B. M. Upton and A. M. Kasko, Chem. Rev., 2016, 116, 22752306.

5 A. J. Ragauskas, G. T. Beckham, M. J. Biddy, R. Chandra, F. Chen, M. F. Davis, B. H. Davison, R. A. Dixon, P. Gilna, M. Keller, P. Langan, A. K. Naskar, J. N. Saddler, T. J. Tschaplinski, G. A. Tuskan and C. E. Wyman, Science, 2014, 344, 1246843.

6 F. G. Calvo-flores and J. A. Dobado, ChemSusChem, 2010, 3, 1227-1235.

7 B. Yang and C. E. Wyman, Biotechnology and Bioengineering, 2004, 86, 88-95.
8 Z. Sun, B. Fridrich, A. de Santi, S. Elangovan and K. Barta, Chem. Rev., 2018, 118, 614-678.

9 Q. Li, Y. He, M. Xian, G. Jun, X. Xu, J. Yang and L. Li, Bioresour. Technol., 2009, 100, 3570-3575.

10 A. Ferrer, A. Vega, A. Rodríguez and L. Jiménez, Bioresour. Technol., 2013, 132, 115-120.

11 X. F. Sun, F. Xu, R. C. Sun, Y. X. Wang, P. Fowler and M. S. Baird, Polymer Degradation and Stability, 2004, 86, 245-256.

12 F. P. Bouxin, A. McVeigh, F. Tran, N. J. Westwood, M. C. Jarvis and S. D. Jackson, Green Chem., 2015, 17, 1235-1242.

13 R. Shu, J. Long, Y. Xu, L. Ma, Q. Zhang, T. Wang, C. Wang, Z. Yuan and Q. Wu, Bioresour. Technol., 2016, 200, 14-22.

14 R. Rinaldi, R. Jastrzebski, M. T. Clough, J. Ralph, M. Kennema, P. C. A. Bruijnincx and B. M. Weckhuysen, Angew. Chemie - Int. Ed., 2016, 55, 8164-8215.

15 T. Renders, S. Van Den Bosch, S. Koelewijn and W. Schutyser, Energy Environ. Sci.,2017, 10, 1551-1557.

16 Q. Song, F. Wang, J. Cai, Y. Wang, J. Zhang, W. Yu and J. Xu, Energy Environ. Sci., 2013, 6, 994.

17 S. Van den Bosch, W. Schutyser, R. Vanholme, T. Driessen, S.-F. Koelewijn, T. Renders, B. De Meester, W. J. J. Huijgen, W. Dehaen, C. M. Courtin, B. Lagrain, W. Boerjan and B. F. Sels, Energy Environ. Sci., 2015, 8, 1748-1763.

18 W. Schutyser, S. Van Den Bosch, T. Renders, T. De Boe, S. Koelewijn, A. Dewaele, T. Ennaert, O. Verkinderen, B. Goderis, C. M. Courtin and B. F. Sels, Green Chem., 2015, 17, 5035-5045.

19 T. Renders, W. Schutyser, S. Van Den Bosch, S. F. Koelewijn, T. Vangeel, C. M. Courtin and B. F. Sels, ACS Catal., 2016, 6, 20552066.

20 S. Van Den Bosch, T. Renders, S. Kennis, S. Koelewijn, G. Van Den Bossche, T. Vangeel, A. Deneyer, D. Depuydt, C. M. Courtin, J. M. Thevelein, W. Schutyser and B. F. Sels, Green Chem., 2017,19, 3313-3326.

21 X. Huang, J. Zhu, T. I. Kor??nyi, M. D. Boot and E. J. M. Hensen, ChemSusChem, 2016, 9, 3262-3267.

22 X. Huang, O. Morales Gonzalez, J. Zhu, T. I. Korányi, M. Boot and E. J. M. Hensen, Green Chem., 2016, 19, 175-187.

23 X. Huang, X. Ouyang, B. M. S. Hendriks, O. M. Morales Gonzalez, J. Zhu, T.I. Koranyi, M. D. Boot and E. J. M. Hensen. Faraday Discuss.,2017, 202,141-156.

24 P. Ferrini and R. Rinaldi, Angew. Chemie - Int. Ed., 2014, 53, 8634-8639.

25 S. J. Sävmarker, M. Larhed, M. V Galkin and J. S. M. Samec, Green Chem., 2017, 19, 5767-5771.

26 E. M. Anderson, L. Michael, R. Katahira, G. T. Beckham, E. M. Anderson, M. L. Stone, R. Katahira, M. Reed, G. T. Beckham and Y. Roma, 2017, 1-10.

27 L. Shuai, M. T. Amiri, Y. M. Questell-Santiago, F. Héroguel, Y. Li, H. Kim, R. Meilan, C. Chapple, J. Ralph and J. S. Luterbacher, Science, 2016, 354, 329-333.

28 X. Hu, Y. Song, L. Wu, M. Gholizadeh and C. Li, ACS Sustainable Chem. Eng., 2013, 1, 1593-1599.

29 J. Wildschut, A. T. Smit, J. H. Reith and W. J. J. Huijgen, Bioresour. Technol., 2013, 135, 58-66.

30 S. Constant, H. L. J. Wienk, A. E. Frissen, P. de Peinder, R. Boelens, D. S. van Es, R. J. H. Grisel, B. M. Weckhuysen, W. J. J. Huijgen, R. J. A. Gosselink and P. C. A. Bruijnincx, Green Chem., 2016, 18, 2651-2665.

31 R. Shu, J. Long, Z. Yuan, Q. Zhanga, T. Wanga, C. Wang and L. Ma, Bioresour. Technol., 2015, 179, 84-90.

32 X. Si, F. Lu, J. Chen, R. Lu, Q. Huang, H. Jiang, E. Taarning and J. Xu, Green Chem., 2017, 19, 4849-4857.

33 B.C. Zhao, B.Y. Chen, S. Yang, T.Q. Yuan, A. Charlton and R.C. Sun, ACS Sustainable Chem. Eng., 2017, 5, 1113-1122.

34 N. U. S. Jr, R. Venditti and D. S. Argyropoulos, Fuel, 2009, 88, 560-565.

35 J.A. Melero, G. Vicente, G. Morales, M. Paniagua, J.M. Moreno, 
R. Roldán , A. Ezquerro, C. Pérez, Applied Catalysis A: General, 2008, 346, 44-51.

36 S. Heikkinen, M. M. Toikka, P. T. Karhunen and I. A. Kilpeläinen, J. Am. Chem. Soc., 2003, 125, 4362-4367.

37 M. R. Sturgeon, S. Kim, K. Lawrence, R. S. Paton, S. C. Chmely, M. Nimlos, T. D. Foust and G. T. Beckham, ACS Sustain. Chem. Eng., 2014, 2, 472-485.

38 P. J. Deuss, C. S. Lancefield, A. Narani, J. G. de Vries, N. J. Westwood and K. Barta, Green Chem., 2017, 19, 2774-2782.

39 P. J. Deuss, M. Scott, F. Tran, N. J. Westwood, J. G. De Vries and K. Barta, J. Am. Chem. Soc., 2015, 137, 7456-7467.

40 C. H. Bartholomew, Applied Catalysis A: General, 2001, 212, 1760.

41 J. A. Moulijn, A. E. Van Diepen and F. Kapteijn, Applied Catalysis A: General, 2001, 212, 3-16.

42 W. J. J. Huijgen, A. T. Smit, J. H. Reith and H. Den Uil, J Chem Technol Biotechnol, 2011, 86, 1428-1438.

43 G. Cheng, X. Zhang, B. Simmons and S. Singh, Energy Environ. Sci., 2015, 8, 436-455.

44 J. K. Ko, Y. Kim, E. Ximenes and M. R. Ladisch, Biotechnology and Bioengineering, 2015, 112, 252-262.

45 P. Ferrini, C. A. Rezende and R. Rinaldi, ChemSusChem, 2016, 9, 3171-3180.

46 P. Bansal, J. H. Lee, M. J. Realff and A. S. Bommarius, FEBS Journal, 2010, 277, 1571-1582.

47 A. Sluiter, B. Hames, R. Ruiz, C. Scarlata, J. Sluiter, D. Templeton and D. Croker. Determination of Structural Carbohydrates and Lignin in Biomass Determination of Structural Carbohydrates and Lignin in Biomass, National Renewable Energy Laboratory, 2008. 